\title{
Current Status of Cashew Leaf and Nut Blight Disease (Cryptosporiopsis spp.) and Screening of Elite Cashew Hybrids Developed in 1996 and 1998 against the Disease in Eastern and Southern Tanzania
}

*Corresponding author

Tel: +255766262655

Fax: +255 272970016

E-mail: majuned@nm-aist.ac.tz ORCID

https://orcid.org/0000-0002-2335-5985

Received November 15, 2018

Revised November 21, 2018

Accepted November 21, 2018

\author{
Dadili Japhet Majune ${ }^{1,2 *}$, Peter Albert Masawe², and Ernest Rashid Mbega' \\ ${ }^{1}$ School of Life Sciences and Bio-engineering the Nelson Mandela African Institution of Science and \\ Technology (NM-AIST), P. O. Box 447, Arusha, Tanzania \\ ${ }^{2}$ Naliendele Agricultural Research Institute, P. O. Box 509, Mtwara, Tanzania
}

\begin{abstract}
Cashew (Anacardium occidentale L.) is an export crop and source of income in Tanzania. However, its productivity is challenged by insect pests and diseases. Cashew Leaf and Nut Blight Disease (CLNBD) caused by Cryptosporipsis spp. has been cited as one of the most devastating diseases in Tanzania. Studies were conducted to investigate incidences and severities of CLNBD on cashew in farmers' fields and elite cashew hybrids developed in 1996 and 1998 in eastern and southern zones of Tanzania. Furthermore, a screen house experiment was conducted to screen these hybrids against CLNBD at Naliendele Agricultural Research Institute (NARI), Mtwara, Tanzania. The results indicated significant differences $(P<0.001)$ in CLNBD incidences and severities in cashew in farmers' fields across Bagamoyo, Nachingwea and Mtwara districts. Further, there were significant differences $(P<0.001)$ among hybrids in CLNBD severities in the screen house experiment. In ranking the elite cashew hybrids, 38 were tolerant and 14 were susceptible to CLNBD. This observation suggests that elite cashew hybrids developed in 1996 and 1998 are more tolerant to CLNBD compared to cashew found in farmers' fields. These findings strongly suggest that the elite cashew hybrids can be recommended for commercial farming in Tanzania.
\end{abstract}

Keywords: Cashew, CLNBD, Fungal, Incidence, Severity

\section{Introduction}

Cashew (Anacardium occidentale L.) is a perennial nut crop, native to Brazil and belongs to the Anacardiaceae family consisting about 75 genera and 700 species (Menge et al., 2013). It was introduced to East Africa by the Portuguese in the $16^{\text {th }}$ century and is now widely cultivated in many tropi-

Research in Plant Disease

pISSN 1598-2262, elSSN 2233-9191

www.online-rpd.org cal countries including Tanzania and Mozambique (Masawe, 2006). It is an important crop for nutrition and income generation worldwide (Menge et al., 2014). The most important products derived from the plant are the apples and nuts. The cashew nuts are processed into kernels which are consumed mostly as snacks. The apples produce juice, jam, candy and alcoholic beverages like wine, gin and brandy. The cashew nut tree provides food, employment, income and the wood used for carpentry while other products derived from it are firewood and charcoal (Akinwale, 2000). Opeke (2005) reported that major cashew producing countries in the world are India, Tanzania, Mozambique, Nigeria, and Guinea- 
Bissau. However, other countries like Ivory Coast, Brazil, Benin and Ghana are also among big producer.

In Tanzania, cashew is the leading export crop in terms of foreign exchange earnings and the main source of cash income for over 300,000 households in South-Eastern Tanzania (Kasuga, 2013). It is estimated that more than $80 \%$ of the national cashew production comes from Mtwara, Lindi and Ruvuma (Tunduru District) regions (CBT, 2015). The area under cashew is estimated to be more than 400,000 hectares in mono or mixed crop production systems. However, the acreage has increased many folds because cashew is now grown in almost all regions in Tanzania (Anonymous, 2017). An average cashew farmer owns 1-2 hectares of cashew trees (Topper et al., 1997). The average yield in farmers' fields ranges from $500 \mathrm{~kg} / \mathrm{ha}$ to $800 \mathrm{~kg} / \mathrm{ha}$ (Masawe, 2006). Cashew production increased rapidly in 1960s towards mid1970s, recording as high as 145,000 Mt. Thereafter, there was drastic decline in production to 16,400 Mt in 1973/1974.
The reasons for the decline in cashew nut production were cited to be powdery mildew disease, insect pests and lack of improved planting materials. The cashew powdery mildew disease was the main reason behind decline in the cashew production (Castellani and Casulli, 1981; Intini, 1987). It can cause crop losses ranging from 70 to $100 \%$ (Sijaona and Shomari, 1987). The disease control measures have been developed and adopted by farmers which are cultural methods including undertaking sanitation, removal of water shoots underneath and pruning branches, as well as the application of fungicides, such as sulphur dusts, wettable powders and water-based formulations (Cassulli, 1981; Intini and Sijaona, 1983; Sijaona et al., 2001; Topper et al., 1997).

In 2003, a survey carried out by pathologists at Naliendele Agricultural Research Institute (NARI) in Tanzania, revealed the presence of a new disease known as "cashew leaf and nut blight" (CLNBD). The disease is caused by a fungal pathogen known as Cryptosporiopsis spp. and was reported

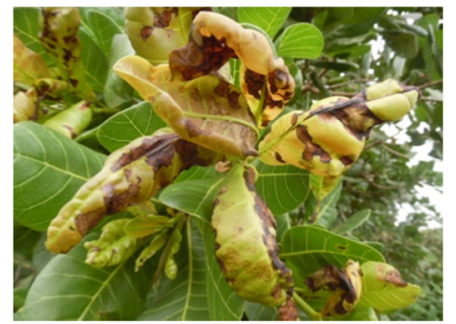

1a. Symptoms of disease on cashew leaves

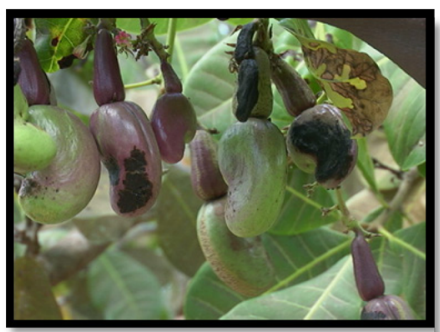

1d. Symptoms of disease on cashew nuts

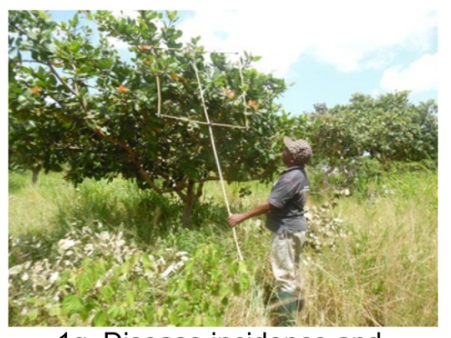

1g. Disease incidence and severity using quadrate in cashew field

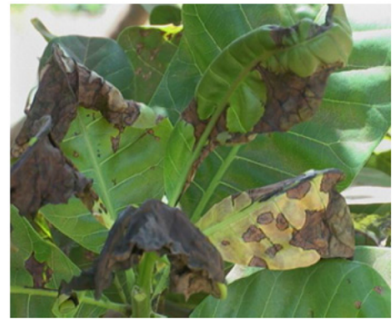

1b. Symptoms of disease on cashew leaves

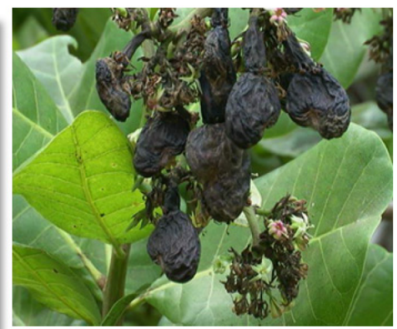

1e. Symptoms of disease on cashew nuts

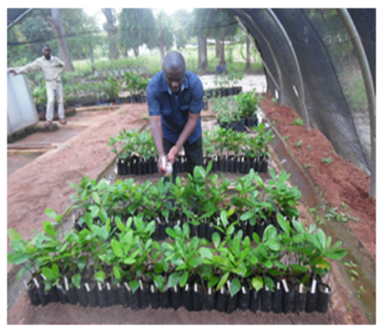

1h. Inoculation process of CLNBD of cashew seedlings in the screen house

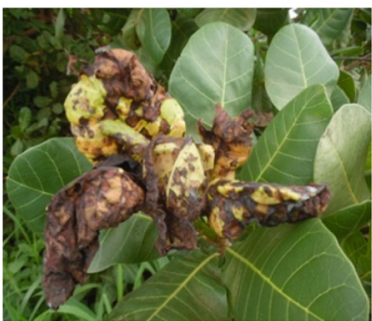

1c. Symptoms of disease on cashew leaves

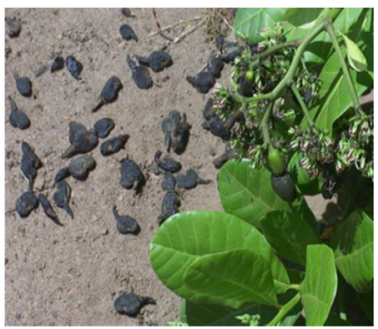

1f. Symptoms of disease on cashew nuts

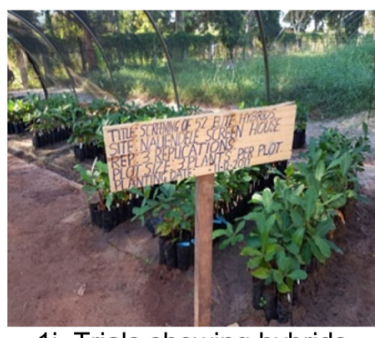

1i. Trials showing hybrids developed in 1996 and 1998 in the screen house

Fig. 1. Effect of the CLNBD on leaves, nuts and trials conducted in the field and screen house. 
to attack cashew for the first time in Tanzania (Sijaona et al., 2005). The disease attacks all tender parts of the plant including young nuts and apples causing annual crop loss up to $48.4 \%$ if not controlled (Fig. 1a-1f). The disease is most active during wet weather especially during off-season rains, where severe infections affect emerging young tender leaves. The disease is characterised by angular lesions, dark tan with dark reddish-brown margins formed on leaves. Lesions subsequently enlarge and coalesce causing large necrotic lesions and finally defoliation. If it rains during fruit setting, the infection of young nuts causes rapid blackening and abscission of nuts, resulting in significant yield losses starting on the seventh day onwards. Usually infections on older nuts result in sunken, 'tar spot'-like lesions that frequently extend onto the apples (Menge et al., 2013, 2014).

In recent years no studies have been undertaken to establish the current status of cashew leaf and nut blight disease on cashew trees growing in farmers' fields in Eastern and Southern zones of Tanzania. However, farmers have been controlling the disease using various fungicides which are expensive. It is the appropriate time to provide farmers with cashew varieties which are resistant or tolerant to the disease in order to reduce cost of production.

NARI is currently working to minimize or completely eliminate the disease. During the 2016/2017 season more than 56 elite cashew hybrids were developed ready to be released for multiplication and distribution to farmers. This study determined the status of these hybrids in-terms of resistance, tolerance and susceptibility to CLNBD. The objectives were to determine the current disease status caused by Cryptosporiopsis spp. in Southern and Eastern zones of Tanzania and to screen selected elite cashew hybrids against the disease. The findings will strengthen information especially for crop resistance in Southern and Eastern zones of Tanzania.

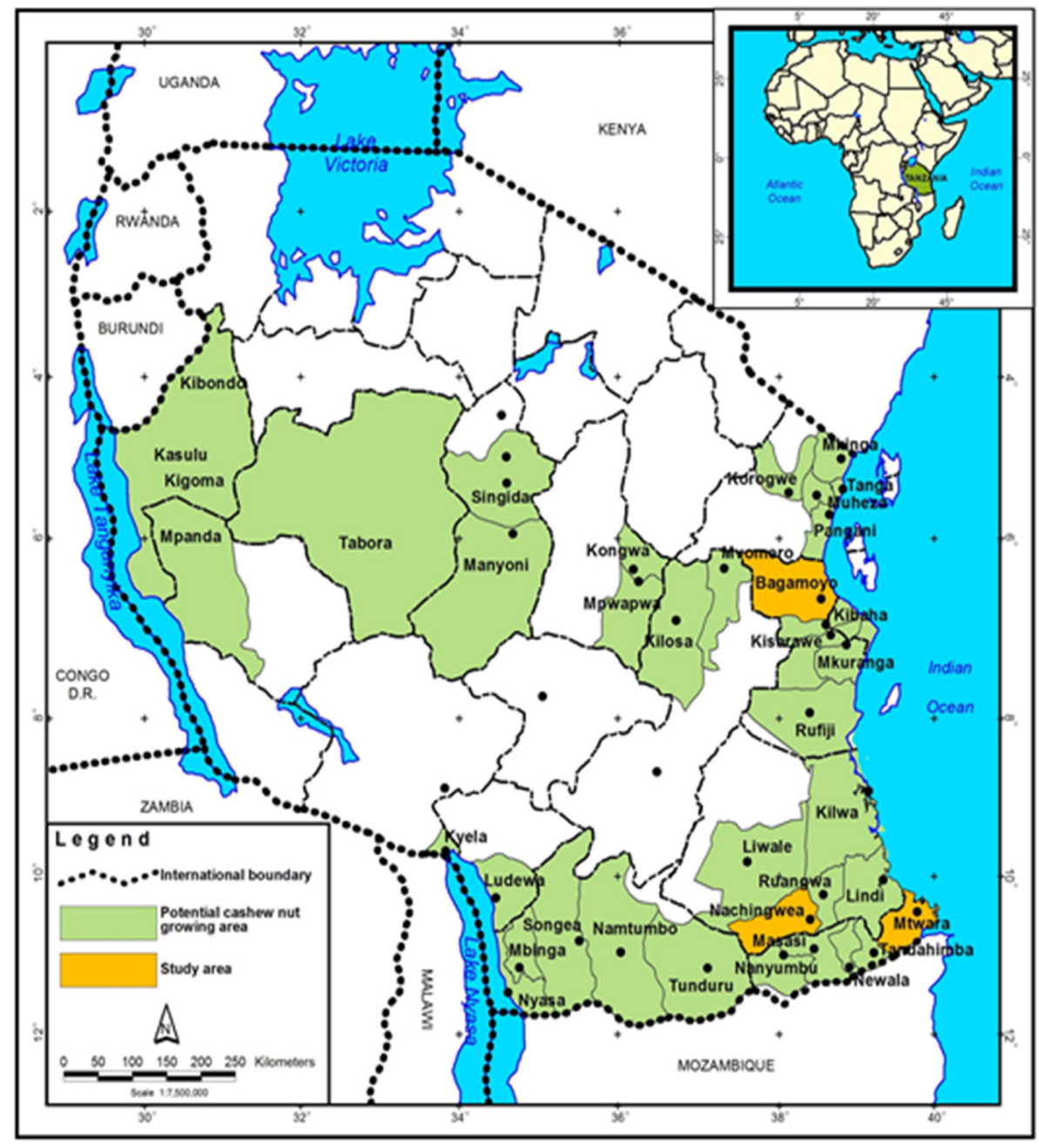

Fig. 2. Map of Tanzania showing potential areas for cashew nut growing and study areas in yellow colour. 


\section{Materials and Methods}

Study area. The study was conducted in Nachingwea which is located at $10^{\circ} 19^{\prime} 46^{\prime} \mathrm{S}, 38^{\circ} 46^{\prime} 46^{\prime} \mathrm{E}$; 442 metres above sea level (masl) (Lindi region), Bagamoyo which is located at $6^{\circ} 31^{\prime} \mathrm{S}$ and $38^{\circ} 55^{\prime} \mathrm{E}$; 19 mals (Coast region) and Mtwara which is located at $10^{\circ} 22^{\prime} 22^{\prime} \mathrm{S}, 40^{\circ} 09^{\prime} 35^{\prime} \mathrm{E}$; 102 masl (Mtwara region) (Fig. 2). These districts were selected because they are the main cashew growing areas in the country and the crop in these areas is being affected by the disease. Also, these areas were selected for developing genetic trials of elite cashew hybrids in 1996 and 1998. A survey in the cashew genetic trials and farmers' field was conducted in these areas, whereas screen house experiments were done at NARI nursery due to presence of infrastructure required for this kind of work.

Field Survey. In order to determine the current status of the disease, a survey was conducted in the cashew growing fields when the new vegetative shoots were emerging, between January and April 2018, and data were recorded for months during the rainy seasons when the pathogen is most active. Three agro-ecological zones were studied with one district per zone depending on the genetic trials. From each district, three villages each three farms were randomly selected with cashew trees aged five to twenty years. Ten cashew trees per farm were assessed. Three rounds of scoring were carried out at intervals of one month for CLNBD incidence and severity for the cashew hybrids developed in 1996 and 1998 and trees from the farmers' fields.

Disease incidence and severity. The disease incidence was determined by placing a quadrat of $1 \mathrm{~m} \times 1 \mathrm{~m}$ on top of the canopy of each cashew tree on opposite sides (North and South). The diseased shoots were counted against total shoots in the quadrat in a given cashew tree and expressed as a percentage. The disease severity was determined by using a scale of 0-6 (Table 1) where 0 represents resistance, 1 to 2 tolerance and 3 to 6 susceptible. A quadrat of $1 \mathrm{~m} \times 1 \mathrm{~m}$ was placed on top of the canopy at opposite sides before scoring the total number of shoots and their disease symptoms using a colour plate disease severity assessment guide for CLNBD (Appendix 1). Data was taken for five shoots using five leaves per shoot starting from the top of the shoot downwards. The final score was based on the formula:

$$
=\sum_{0}^{6}\left(0^{*} \mathrm{~L}\right)+\left(1^{*} \mathrm{~L}\right)+\left(2^{*} \mathrm{~L}\right)+\left(3^{*} \mathrm{~L}\right)+\left(4^{*} \mathrm{~L}\right)+\left(5^{*} \mathrm{~L}\right)+\left(6^{*} \mathrm{~L}\right) / 50(\mathrm{~L}) .
$$

Whereby ' $L$ ' represents the number of leaves scored in two quadrates north and south directions per tree.

Screen house experiment. The elite cashew hybrids developed in 1996 and 1998 were screened in a screen house at NARI. Cashew seeds were raised in polythene tubes (diameter $10 \mathrm{~cm}$ and height $20 \mathrm{~cm}$ ) filled with forest soil collected under cashew trees as growth media. Cashew seeds started germinating at $14 \mathrm{~d}$ and between 30 and $45 \mathrm{~d}$ rootstalks were ready for grafting. Scions for grafting were collected from selected mother trees of the elite cashew hybrids developed in 1996 and 1998. After 45 d, the grafted cashew seedlings had more than six tender leaves which were suitable for inoculation. The treatments were arranged in a Completely Randomized Design (CRD), with three cashew hybrids per plot and three replicated plots. There were two control varieties, the resistant AZA) and the susceptible AC4. The inoculum was prepared by collecting leaves infected by CLNBD with a 5-6 rating of disease and adding them to $20 \mathrm{~L}$ of water for $24 \mathrm{~h}$ with periodic mixing. The suspension was filtered to remove leaf debris and the seedlings in each plot were uniformly sprayed with $1 \times 10^{6}$ conidia per $\mathrm{ml}$, four times each at $7 d$ intervals for 28 days (Menge et al., 2014) of the same batch of inoculum. Thirty six mls per plot were inoculated on grafted seedlings and covered with a polythene sheet for $24 \mathrm{~h}$ to maintain relative humidity of about $90-95 \%$ at $24-28^{\circ} \mathrm{C}$ (Menge et al., 2014). These inoculated grafted

Table 1. The scale of cashew leaf and nut blight disease showing levels, intervals and mid-point in percentages

\begin{tabular}{cccccccc}
\hline Level & $\mathbf{0}$ & $\mathbf{1}$ & $\mathbf{2}$ & $\mathbf{3}$ & $\mathbf{4}$ & $\mathbf{5}$ & $\mathbf{6}$ \\
\hline Interval & 0 & $1-20$ & $21-40$ & $41-60$ & $61-80$ & $71-99$ & 90 \\
Mid-point (\%) & 0 & 10.5 & 30.5 & 50.5 & 70.5 & \multicolumn{2}{c}{ Susceptible } \\
\hline Grade & Resistance & \multicolumn{2}{c}{ Tolerant } & & \\
\hline
\end{tabular}

Source; NARI Pathologists (2012). 
seedlings were examined and scored for disease occurrence daily for $7 \mathrm{~d}$ after each round of inoculation. Fig. 1a$1 c$, show disease symptoms on leaves while those of tender nuts are found in Fig. 1d-1f. The photographs for the trials undertaken in the field and in the screen house are shown in Fig. $1 \mathrm{~g}-1 \mathrm{i}$. Some varieties scoring 0 were regarded as resistant, while those with scores of 1-2 and scores of 3-6 were regarded as tolerant and susceptible to CLNBD, respectively.

Statistical analysis. Data were collected from farmers' fields, cashew genetic trials of elite hybrids and screen house experiment. Data from the fields and screen house experiment were analysed using statistical analysis package Genstat, $16^{\text {th }}$ Edition, whereas Duncan Multiple Range Test was used to separate the means and Least Significant Difference (LSD) test at $(P<0.05)$.

\section{Results}

Cashew genetic trials. Three rounds of monitoring the trials were undertaken and the results for analysis of variance for \% incidence and severity for the elite hybrids developed in 1996 and 1998 are presented in Tables 2 and 4. Results showed that there were statistically significant differences between hybrids in incidence $(P<0.05)$ and severity $(P<0.01$, $P<0.001)$ in the sites studied. Trial means for \% incidence for the elite hybrids developed in 1996 and 1998 at Chambezi were 15.00 and 15.44, respectively. On the other hand, trial means for \% incidence for the hybrids developed in 1996 and 1998 at Nachingwea were 17.25 and 19.40, respectively. The trial means for severity for the same hybrids at Chambezi developed in 1996 and 1998 were 8.98 and 9.79, respectively; while for those developed at Nachingwea were 8.03 and
11.74. The least significant differences (LSD) for \% incidence for the hybrids developed in 1996 and 1998 at Chambezi were 17.56 and 21.37 respectively. On the other hand, the LSD for severity of hybrids developed in 1996 and 1998 at Chambezi were 10.25 and 9.39 respectively. The LSD for \% incidence for the same hybrids at Nachingwea developed in 1996 and 1998 were 21.37 and 15.49, respectively; while the LSD for severity of those developed hybrids at Nachingwea were 9.97 and 11.85 respectively. When comparing \% incidence for elite cashew hybrids developed in 1996 at Chambezi, hybrid C10-4-11, ranked first but differed significantly from the last three hybrids (C13-1, C10-4-15 and C3-1) only (Table 3). Data on severity for elite hybrids developed in 1996 at Chambezi indicate that, hybrid C10-4-11, ranked first but differences were not significant with 26 hybrids. However, it differed significantly with the last four hybrids C9-3, C13-1, C3-1 and C10-4-15 (Table 3).

When comparing \% incidence for elite hybrids developed in 1996 at Nachingwea, hybrid C15-4 ranked first but was statistically significantly different from the last two hybrids C10-4-15 and C7-1-6 (Table 3). On the other hand, when comparing severity for elite hybrids developed in 1996 at Nachingwea, hybrid C15-4 ranked first. However, differences were not significant from other hybrids except the last two (C10-4-15 and C7-1-6) (Table 3).

Results of \% incidence on elite hybrids developed in 1998 at Chambezi, hybrids H7.3 ranked first but differences were not significant from the others, except the last three hybrids H39.4, H29.1 and H6.3 (Table 5). When comparing severity for elite hybrids developed in 1996 at Chambezi, hybrid H7.3 ranked first but was not significantly different from the others, except the last five hybrids H34.3, H19.1, H39.4, H29.1 and H6.3 (Table 5).

Table 2. Analysis of variance for \% incidence and severity for cashew leaf and nut blight disease for "1996 hybrids" at Chambezi and Nachingwea respectively

\begin{tabular}{|c|c|c|c|c|c|}
\hline \multirow{2}{*}{ Source } & \multirow[b]{2}{*}{ Degree of freedom } & \multicolumn{4}{|c|}{ Mean squares } \\
\hline & & $\%$ Incidence & Severity & $\%$ Incidence & Severity \\
\hline Rep & 2 & 210.9 & 134.74 & 103.2 & 8.93 \\
\hline Error & 50 & 114.7 & 39.05 & 169.8 & 32.84 \\
\hline Mean & & 15 & 8.98 & 17.25 & 9.79 \\
\hline CV (\%) & & 71.6 & 69.6 & 75.5 & 58.5 \\
\hline
\end{tabular}


Table 3. Ranking means for \% incidence and severity for elite hybrids developed "1996" at Chambezi and Nachingwea respectively

\begin{tabular}{|c|c|c|c|c|c|c|}
\hline No & Hybrids & $\%$ Incidence & Severity & Hybrids & \% Incidence & Severity \\
\hline 1 & C10-4-11 & $2.03 a$ & $0.49 a$ & C15-4 & $1.28 \mathrm{a}$ & $0.89 a$ \\
\hline 2 & $C 5-1$ & $2.14 a$ & $3.82 a$ & C14-4 & $4.93 a$ & $2.80 a$ \\
\hline 3 & C19-4 & $4.04 a$ & $2.87 a$ & C15-2-8 & $9.71 a$ & $3.88 a$ \\
\hline 4 & C1-4 & $6.66 a$ & $5.04 a$ & C1-2 & $9.76 a$ & $4.81 a$ \\
\hline 5 & C15-4 & $6.68 a$ & $5.83 a$ & C19-4 & $9.84 a$ & $8.52 a$ \\
\hline 6 & C14-4 & $8.43 a$ & $5.69 a$ & $C 25-3$ & $10.81 a$ & $4.59 a$ \\
\hline 7 & C1-3 & $8.98 a$ & $5.92 a$ & C15-2-26 & $11.00 a$ & $10.58 a$ \\
\hline 8 & C15-2-2 & $9.52 a$ & $5.57 a$ & C3-1 & $12.09 a$ & $7.33 a$ \\
\hline 9 & C15-2-8 & $10.14 a$ & 7.18a & C15-3 & $13.21 \mathrm{a}$ & 9.98a \\
\hline 10 & C15-3 & $12.00 \mathrm{a}$ & $10.58 a$ & C4-1 & $14.18 a$ & $7.91 a$ \\
\hline 11 & $\mathrm{C} 1-2$ & $12.41 \mathrm{a}$ & $4.89 a$ & C7-1-13 & $14.66 a$ & $7.18 a$ \\
\hline 12 & $C 22-4$ & $12.51 a$ & $8.14 a$ & C13-2 & $15.21 a$ & $4.93 a$ \\
\hline 13 & C4-1 & $13.01 \mathrm{a}$ & $6.99 a$ & C7-2 & $15.23 a$ & $9.17 a$ \\
\hline 14 & $C 7-2$ & $14.86 a$ & $5.42 a$ & C5-1 & $15.37 a$ & $14.96 a$ \\
\hline 15 & C15-2-26 & $15.44 a$ & $11.09 a$ & C10-4-11 & $15.77 a$ & $8.90 a$ \\
\hline 16 & C13-4 & $16.41 a$ & $9.01 a$ & C13-1 & $15.88 a$ & $5.88 a$ \\
\hline 17 & C10-1 & $17.73 a$ & $11.03 a$ & C10-1 & $16.26 a$ & $9.33 a$ \\
\hline 18 & C7-1-6 & $18.03 a$ & $9.31 \mathrm{a}$ & C15-2-2 & 17.86a & $9.36 a$ \\
\hline 19 & C5-2 & $18.23 a$ & $7.93 a$ & C1-3 & $18.02 \mathrm{a}$ & $11.30 \mathrm{a}$ \\
\hline 20 & C9-3 & $22.02 a$ & $15.12 b$ & $C 22-4$ & $21.53 a$ & $12.01 \mathrm{a}$ \\
\hline 21 & C13-2 & $22.22 a$ & $9.87 a$ & $\mathrm{C} 1-4$ & $21.55 a$ & $14.97 a$ \\
\hline 22 & C7-1-13 & $22.32 a$ & $11.24 a$ & C9-3 & $22.73 a$ & $12.47 a$ \\
\hline 23 & $C 25-3$ & $22.74 a$ & $11.77 a$ & C5-2 & $25.84 a$ & $13.49 a$ \\
\hline 24 & C13-1 & $24.72 b$ & $16.95 c$ & $\mathrm{C} 13-4$ & $26.41 a$ & $17.27 \mathrm{c}$ \\
\hline 25 & C10-4-15 & $32.48 c$ & $23.09 e$ & C10-4-15 & $30.38 b$ & $16.40 \mathrm{~b}$ \\
\hline 26 & C3-1 & $33.15 c$ & $18.527 d$ & C7-1-6 & $34.69 c$ & 14.79a \\
\hline
\end{tabular}

Table 4. Analysis of variance for \% incidence and severity for cashew leaf and nut blight disease for "1998 hybrids" at Chambezi and Nachingwea respectively

\begin{tabular}{lccccc}
\hline \multirow{2}{*}{ Source } & \multicolumn{5}{c}{ Mean squares } \\
\cline { 2 - 5 } & Degree of freedom & \% Incidence & Severity & \% Incidence & Severity \\
\hline Rep & 2 & 100.8 & 15.39 & 241.69 & 123.73 \\
Hybrids & 25 & $260.60^{*}$ & $82.48^{* *}$ & $185.51^{* *}$ & $107.46^{* *}$ \\
Error & 50 & 165.7 & 32.06 & 89.27 & 52.17 \\
Mean & & 15.44 & 8.03 & 19.4 & 11.74 \\
L.S.D & & 21.11 & 9.29 & 15.49 & 11.85 \\
CV (\%) & & 83.4 & 70.5 & 48.7 & 61.5 \\
\hline
\end{tabular}

The \% incidence for elite hybrids developed in 1998 at Nachingwea indicate that, hybrid $\mathrm{H} 8.3$ ranked first but was not significantly different from the others, except the last eight hybrids H19.1, H1.3, H26.1, H39.4, H64.4, H13.1, H29.1 and H34.1 (Table 5). When comparing severity for elite hybrids developed in 1998 at Nachingwea, hybrid H8.3 ranked first but was not significantly different from other hybrids, except the last five hybrids H26.1, H64.4, H34.1, H13.1 and H29.1 (Table 5).

Farmers field survey. Results from the farmers' fields (local cultivars) showed that there were highly significant 
Table 5. Ranking means for \% incidence and severity for elite hybrids developed "1998" at Chambezi and Nachingwea respectively

\begin{tabular}{ccccccc}
\hline No & Hybrids & \% Incidence & Severity & Hybrids & \% Incidence & Severity \\
\hline 1 & $\mathrm{H} 7.3$ & $1.21 \mathrm{a}$ & $0.483 \mathrm{a}$ & $\mathrm{H} 8.3$ & $5.76 \mathrm{a}$ & $2.23 \mathrm{a}$ \\
2 & $\mathrm{H} 51.2$ & $4.96 \mathrm{a}$ & $0.897 \mathrm{a}$ & $\mathrm{H} 24.3$ & $7.39 \mathrm{a}$ & $4.13 \mathrm{a}$ \\
3 & $\mathrm{H} 8.3$ & $5.58 \mathrm{a}$ & $4.263 \mathrm{a}$ & $\mathrm{H} 49.4$ & $8.71 \mathrm{a}$ & $3.82 \mathrm{a}$ \\
4 & $\mathrm{H} 51.4$ & $5.76 \mathrm{a}$ & $2.830 \mathrm{a}$ & $\mathrm{H} 59.4$ & $10.79 \mathrm{a}$ & $3.77 \mathrm{a}$ \\
5 & $\mathrm{H} 59.4$ & $6.37 \mathrm{a}$ & $2.227 \mathrm{a}$ & $\mathrm{H} 51.4$ & $13.43 \mathrm{a}$ & $6.53 \mathrm{a}$ \\
6 & $\mathrm{H} 49.4$ & $7.90 \mathrm{a}$ & $0.903 \mathrm{a}$ & $\mathrm{H} 37.4$ & $14.07 \mathrm{a}$ & $6.57 \mathrm{a}$ \\
7 & $\mathrm{H} 24.3$ & $10.55 \mathrm{a}$ & $5.037 \mathrm{a}$ & $\mathrm{H} 8.1$ & $14.11 \mathrm{a}$ & $10.71 \mathrm{a}$ \\
8 & $\mathrm{H} 68.4$ & $10.82 \mathrm{a}$ & $7.153 \mathrm{a}$ & $\mathrm{H} 6.1$ & $14.15 \mathrm{a}$ & $7.53 \mathrm{a}$ \\
9 & $\mathrm{H} 37.4$ & $11.57 \mathrm{a}$ & $5.183 \mathrm{a}$ & $\mathrm{H} 7.3$ & $14.54 \mathrm{a}$ & $9.83 \mathrm{a}$ \\
10 & $\mathrm{H} 43.4$ & $11.80 \mathrm{a}$ & $4.833 \mathrm{a}$ & $\mathrm{H} 38.4$ & $14.72 \mathrm{a}$ & $9.23 \mathrm{a}$ \\
11 & $\mathrm{H} 2.1$ & $12.55 \mathrm{a}$ & $6.957 \mathrm{a}$ & $\mathrm{H} 2.1$ & $15.12 \mathrm{a}$ & $7.06 \mathrm{a}$ \\
12 & $\mathrm{H} 8.1$ & $12.58 \mathrm{a}$ & $6.403 \mathrm{a}$ & $\mathrm{H} 6.3$ & $17.28 \mathrm{a}$ & $7.16 \mathrm{a}$ \\
13 & $\mathrm{H} 6.1$ & $13.37 \mathrm{a}$ & $10.667 \mathrm{a}$ & $\mathrm{H} 42.4$ & $17.62 \mathrm{a}$ & $10.34 \mathrm{a}$ \\
14 & $\mathrm{H} 38.4$ & $14.02 \mathrm{a}$ & $5.170 \mathrm{a}$ & $\mathrm{H} 68.4$ & $18.41 \mathrm{a}$ & $11.02 \mathrm{a}$ \\
15 & $\mathrm{H} 26.1$ & $15.43 \mathrm{a}$ & $7.547 \mathrm{a}$ & $\mathrm{H} 34.3$ & $18.65 \mathrm{a}$ & $11.18 \mathrm{a}$ \\
16 & $\mathrm{H} 19.1$ & $15.83 \mathrm{a}$ & $15.807 \mathrm{c}$ & $\mathrm{H} 23.3$ & $20.68 \mathrm{a}$ & $16.10 \mathrm{a}$ \\
17 & $\mathrm{H} 1.3$ & $16.69 \mathrm{a}$ & $11.103 \mathrm{a}$ & $\mathrm{H} 43.4$ & $23.41 \mathrm{a}$ & $13.35 \mathrm{a}$ \\
18 & $\mathrm{H} 23.3$ & $17.24 \mathrm{a}$ & $7.380 \mathrm{a}$ & $\mathrm{H} 51.2$ & $24.10 \mathrm{a}$ & $14.60 \mathrm{a}$ \\
19 & $\mathrm{H} 64.4$ & $17.72 \mathrm{a}$ & $11.783 \mathrm{a}$ & $\mathrm{H} 19.1$ & $25.10 \mathrm{~b}$ & $15.88 \mathrm{a}$ \\
20 & $\mathrm{H} 34.1$ & $17.75 \mathrm{a}$ & $10.713 \mathrm{a}$ & $\mathrm{H} 1.3$ & $25.10 \mathrm{~b}$ & $16.13 \mathrm{a}$ \\
21 & $\mathrm{H} 42.4$ & $19.40 \mathrm{a}$ & $5.480 \mathrm{a}$ & $\mathrm{H} 26.1$ & $27.29 \mathrm{c}$ & $17.52 \mathrm{~b}$ \\
22 & $\mathrm{H} 34.3$ & $24.31 \mathrm{a}$ & $13.363 \mathrm{~b}$ & $\mathrm{H} 39.4$ & $27.69 \mathrm{~d}$ & $15.58 \mathrm{a}$ \\
25 & $\mathrm{H} 13.1$ & $25.14 \mathrm{a}$ & $9.930 \mathrm{a}$ & $\mathrm{H} 64.4$ & $30.29 \mathrm{e}$ & $17.89 \mathrm{~b}$ \\
\hline 2 & $\mathrm{H} 39.4$ & $28.55 \mathrm{~b}$ & $16.177 \mathrm{~d}$ & $\mathrm{H} 13.1$ & $30.98 \mathrm{e}$ & $21.45 \mathrm{c}$ \\
& $\mathrm{H} 29.1$ & $29.72 \mathrm{~b}$ & $17.627 \mathrm{e}$ & $\mathrm{H} 29.1$ & $31.99 \mathrm{e}$ & $24.12 \mathrm{~d}$ \\
\hline
\end{tabular}

Table 6. Analysis of variance for \% incidence and severity for cashew leaf and nut blight disease for "Survey done at Mtwara, Nachingwea and Bagamoyo districts"

\begin{tabular}{lccc}
\hline & \multicolumn{3}{c}{ Mean squares } \\
\hline Source & $\begin{array}{c}\text { Degree of } \\
\text { freedom }\end{array}$ & \% Incidence & Severity \\
\hline District & 2 & $13831.2^{* * *}$ & $3375.8^{* * * *}$ \\
Error & 87 & 237.80 & 145.00 \\
Mean & & 46.63 & 26.00 \\
L.S.D & & 7.91 & 6.18 \\
CV (\%) & & 33.10 & 46.30 \\
\hline
\end{tabular}

differences $(P<0.001)$ (Table 6$)$ between cashew growing districts in \% incidence and severity of the disease. The means for \% incidence and severity in farmers' field were 46.63 and 26 respectively; which are very high compared to elite hybrids developed in 1996 and 1998 (Table 2 and Table 4).
When comparing the districts in incidence and severity of the disease in farmers' fields, Bagamoyo district had the lowest incidence and severity followed by Nachingwea district whereas the last was Mtwara district (Fig. 3). The lower the \% incidence and severity the lower the CLNBD in the field.

Screening of seedlings in the screen house. After inoculation of seedlings with conidia of Cryptosporiopsis spp. small brown spots appeared on the young leaves at the first time of observations, $7 \mathrm{~d}$. The spots enlarged and coalesced as the time increased and resembled the symptoms observed in the field. The analysis of variance showed that there were highly significant differences between cashew elite hybrids in all trials $(P<0.001)$. Trial means for severity of elite cashew hybrids developed in 1996 and 1998 in the screen house were 4.28 and 4.71 , respectively. Their least significant 
Graph representing Districts surveyed in Tanzania

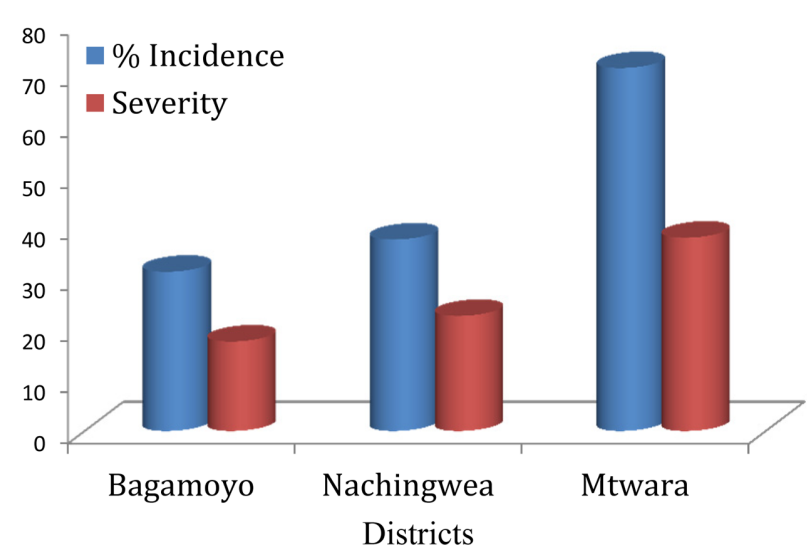

Fig. 3. Ranking means for \% incidence and severity for farmers' field surveyed at Nachingwea, Mtwara and Bagamoyo districts.

Table 7. Analysis of variance for severity for cashew leaf and nut blight disease for elite cashew hybrids developed "1996 and 1998" in the screen house at NARI

\begin{tabular}{lccc}
\hline \multirow{2}{*}{ Source } & \multicolumn{3}{c}{ Mean squares } \\
\cline { 2 - 4 } & $\begin{array}{c}\text { Degree of } \\
\text { freedom }\end{array}$ & Severity (1996) & Severity (1998) \\
\hline Rep & 2 & 15.30 & 1.44 \\
Hybrids & 27 & $22.49^{* * *}$ & $29.49^{* * * *}$ \\
Error & 54 & 5.46 & 4.08 \\
Mean & & 4.28 & 4.71 \\
L.S.D & & 3.83 & 3.28 \\
CV (\%) & & 54.60 & 42.60 \\
\hline
\end{tabular}

differences (LSD) for all trials are 3.83 and 3.28 respectively (Table 7). When comparing severity for elite cashew hybrids developed in 1996 in the screen house, variety AZA2 ranked first with low severity but was not significantly different from 28 hybrids, except the last three hybrids and variety AC4 (Fig. 4). When comparing severity for elite cashew hybrids developed in 1998 in the screen house, variety AZA2 again ranked first in-terms of low disease severity; however, significant differences were observed it was compared with the last eleven hybrids and variety AC4 (Fig. 5).

\section{Discussion}

The elite cashew hybrids developed in 1996 and 1998. The overall highest score \% incidence and severity for elite hybrids developed in 1996 and 1998 are 19.4 and 11.74 respectively. These findings compare to the farmers field results where highest \% incidence and severity at Nachingwea, Bagamoyo and Mtwara districts were 46.63 and 26.0 respectively. Indeed, most unimproved cashew varieties have a lower level of resistance or tolerance than the hybrids (Masawe 2006; Sijaona, 2013). The tolerance of the elite hybrids would benefit farmers with reduced fungicide costs and higher yields.

Farmers field survey. The farmers field survey results in-

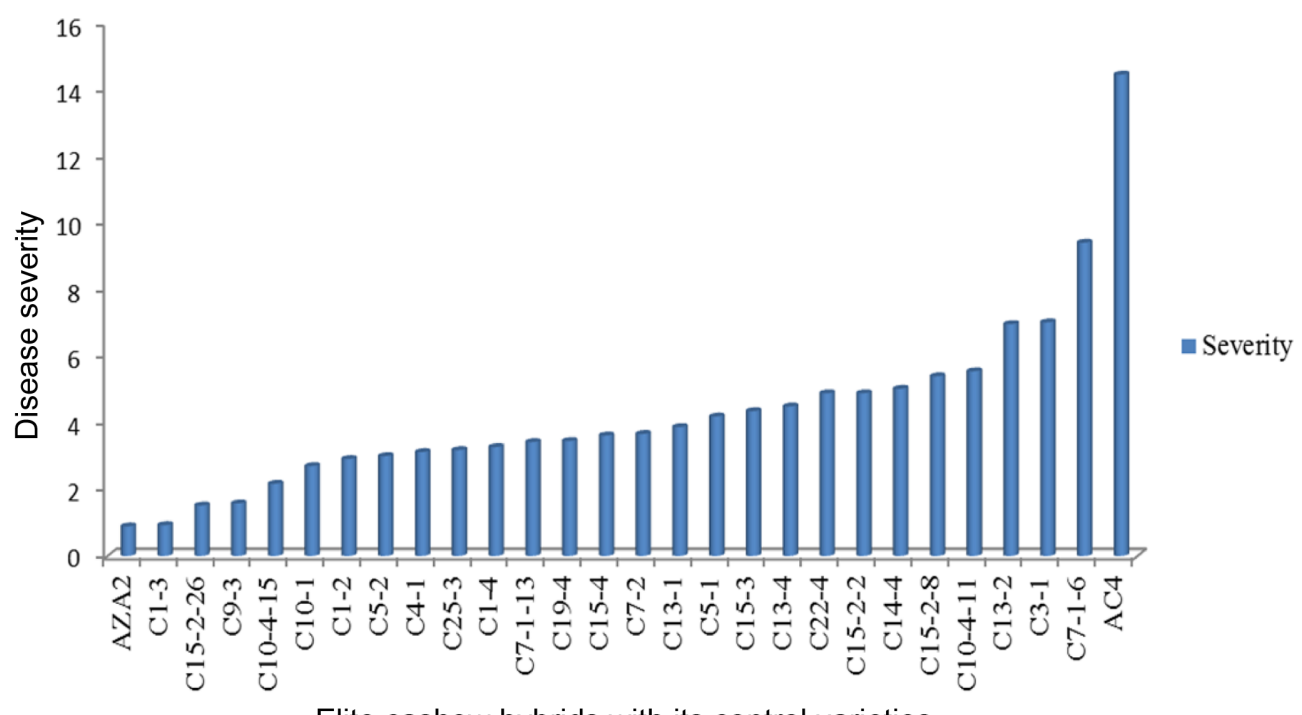

Elite cashew hybrids with its control varieties

Fig. 4. Ranking means for severity for elite cashew hybrids developed "1996" in the screen house at NARI. 


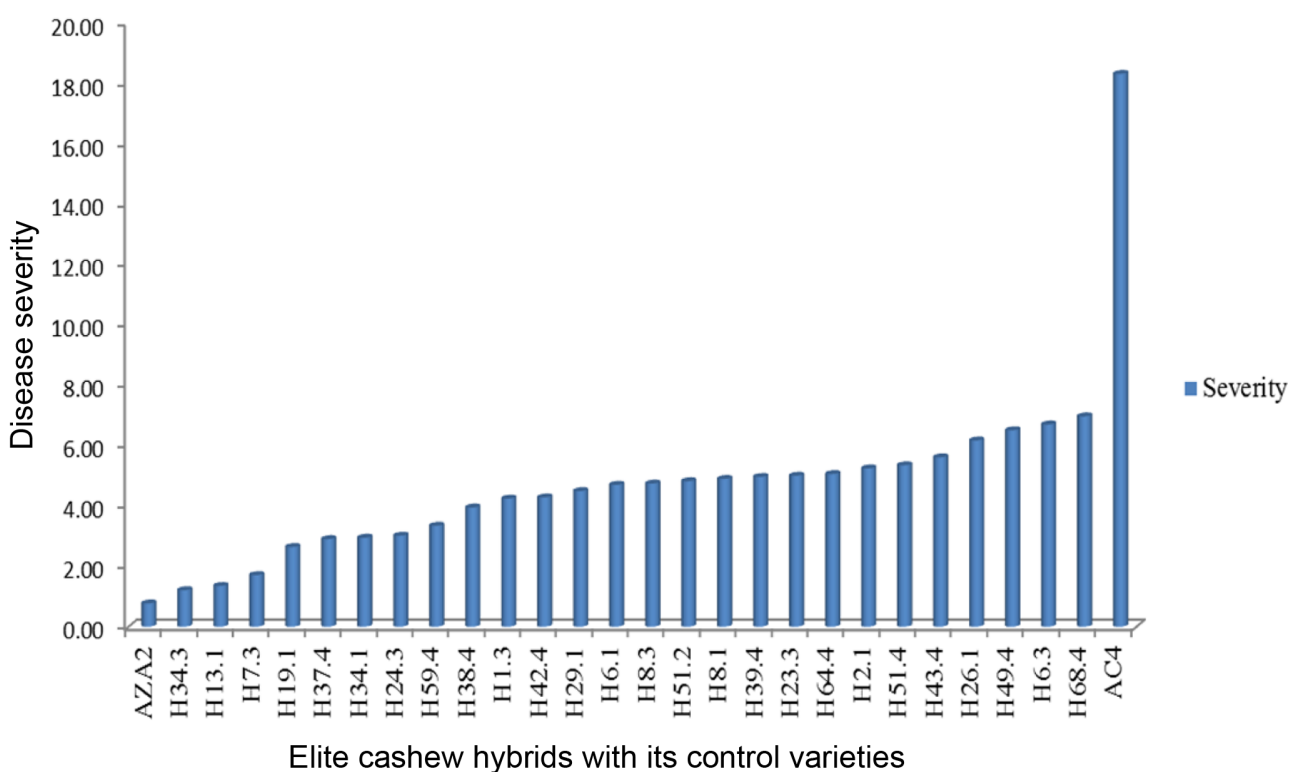

Fig. 5. Ranking means for severity for elite cashew hybrids developed "1998" in the screen house at NARI.

dicated that the highest \% incidence and severity at Nachingwea, Bagamoyo and Mtwara districts were 46.63 and 26.00 respectively. The results suggested that the materials used by farmers in the surveyed areas are in group three which is the susceptible group. The susceptible group is the one vulnerable to infection by the CLNBD when compared to other groups. The cashew planting materials used by farmers are highly affected by CLNBD. Through this study farmers are advised to use elite cashew hybrids developed in 1996 and 1998 which are resistant or tolerant to CLNBD and are available at NARI.

Screening of seedlings in the screen house. The mean severity of the disease for the elite hybrids developed in 1996 and 1998, 4.28 and 4.71 respectively, was very low in the tolerant group, possibly due to size of the tree canopy. However, analysis of variance showed that the elite hybrids had variable tolerance $(P<0.001)$. The screen house studies showed that variety AZA2 (positive control) rank first with no significant different between hybrids in all trials. On the other hand, variety AC4 (negative control) ranked last and differences in disease severity were highly significant from all the other genotypes in all trials. This suggests that all the elite cashew hybrids rank in AZA2 group are tolerant to cashew planting materials. However, these materials are to be adopted by cashew growing farmers for high yielding and tolerant to CLNBD.

\section{Conclusion and Recommendation}

This study revealed that farmers cultivating cashew in Nachingwea, Bagamoyo and Mtwara districts are using cashew planting materials which susceptible to CLNBD. However, a screen house study with inoculation by the pathogen showed CLNBD tolerance in 38 elite cashew hybrids developed in 1996 and 1998. Based on these findings farmers of these three districts and other areas with similar climatic conditions in the country are advised to cultivate these elite cashew hybrids in order to reduce the cost of production, increase household income which will also lead into increased foreign exchange earnings for the country. It is recommended that the study be undertaken all over cashew growing areas in the country so that if similar results are achieved it will justify up-scaling of these hybrids for higher incomes and sustainable revenue for the government.

\section{Conflicts of Interest}

No potential conflict of interest relevant to this article was reported. 


\section{Acknowledgements}

The authors acknowledge the Nelson Mandela African Institution of Science and Technology for providing an opportunity to undertake a course in Applied Plant Pathology which created grounds for development of this document. Special thanks go to the Cashew Research Programme at Naliendele Agricultural Research Institute for financial support of course work and field practical. Special thanks also go to Dr. Elly Kafiriti for language and linguistics proof reading of the manuscript before submission.

\section{References}

Akinwale, T. O. 2000. Cashew apple juice: Its use in fortifying the nutritional quality of some tropical fruits. Eur. Food Res. Technol. 211:205-207.

Castellani, E. and Casulli, F. 1981. Observazioni preliminarisu Oidium anacardii Noack, agente del mal biancodell'anacardio in Tanzania. Riv. Agric. Subtrop. Trop. 75: 211-222.

Intini, M. 1987. Phytopathological aspects of cashew (Anacardium occidentale L.) in Tanzania. Int. J. Trop. Plant Dis. 5: 115-130.

Intini, M. and Sijaona, M. E. R. 1983. Calendar of disease control with reference to the phonological phase of cashew (Anacardium occidentale L.) in Tanzania. Riv. Agric. Subtrop. Trop. 76: 419-422.

Kasuga L. J. F. 2013. Status of the Cashew industry in Tanzania. In: Proceedings of the Second International Cashew Conference. eds. by P. A. L. Masawe, J. F. O. Esegu, L. J. F. Kasuga, E. E. Mneney and
D. Mujuni, pp. 177-182. CAB International, Wallingford, UK.

Masawe, P. A. L. 2006. Tanzanian cashew cultivars: Selected clones; Cashew Research Programme. Naliendele Agricultural Research Institute, Mtwara, Tanzania. 64 pp.

Menge, D., Makobe, M., Shomari, S. and Tiedemann, A. 2013. Effect of environmental conditions on the growth of Cryptosporiopsis spp. causing leaf and nut blight on cashew (Anacardium occidentale Linn.). J. Yeast Fungal Res. 4: 12-20.

Menge, D., Makobe, M., Agboton, B., Shomari, S. and Tiedemann, A. 2014. Biology and infection mechanisms of Cryptosporiopsis spp. fungus causing blight disease on Cashew (Anacardium occidentale L.). J. Plant Sci. 2: 266-275.

Opeke, L. K. 2005. Tropical commodity tree crops. Spectrum Books Ltd., Ibadan, Nigeria. 86 pp.

Sijaona, M. E. R. 1984. Investigation into the effectiveness of sulphur W.P. against Oidium anacardii Noack on five-cashew tree types at Naliendele. Riv. Agric. Subtrop. Trop. 78: 199-209.

Sijaona, M. E. R. 2013. Important diseases and insect pests of cashew in Tanzania. Naliendele Agricultural Research Institute. Mtwara, Tanzania. 44 pp.

Sijaona, M. E. R. and Shomari, S. H. 1987. The powdery mildew disease of cashew in Tanzania. TARO Newsletter 11:4-5.

Sijaona, M. E. R., Reeder, R. H. and Waller, J. M. 2005. Cashew leaf and nut blight - A new disease of cashew in Tanzania caused by Cryptosporiopsis spp. Plant Pathol. 55: 576.

Topper, C. P., Boma, F. and Mhando, H. 1997. Evaluation of fungicides for the control of powdery mildew (Oidium anacardii Noack) on cashew in Tanzania. In: Proceedings of the International cashew and coconut conference, ed. by C. P. Topper, pp. 254-259. BioHybrids International Ltd., Reading, UK. 